\title{
Exploring beginner teachers' sources of knowledge for teaching Literature in ESL classrooms
}

\author{
Nhlanhla Mpofu ${ }^{1}$ and Lizette de Jager ${ }^{2}$ \\ ${ }^{1}$ Department Centre for Teaching, Learning and Programme Development, Sol Plaatje UniversityP/Bag x5008, \\ Kimberley, 8300, South Africa \\ ${ }^{2}$ Department of Humanities Education, University of Pretoria, Groenkloof Campus, Leyds Street \\ Pretoria, 0027, South Africa
}

Corresponding author: Nhlanhla Mpofu, E-mail: nhlanhla.mpofu@spu.ac.za

\begin{abstract}
The purpose of this study was to identify beginner teachers' sources of knowledge for teaching literature in the English Second Language (ESL) classroom. A review of the literature on ESL teachers' knowledge indicated a paucity of studies that focus specifically on teaching knowledge for Literature as a stand-alone subject in ESL. In addition, ESL teacher training in most countries seemingly focuses on preparing pre-service teachers for language teaching rather than literature. To identify the sources of teaching knowledge for Literature teachers, this study adopted an interpretivist epistemological worldview and used a qualitative single case study design. Data were collected using non-participant observations and semi-structured interviews from four purposively selected Literature in English beginner teachers. Quality and ethical considerations were upheld in this study using a number of strategies. Inductive thematic analysis was used for data analysis. The analysis resulted in three sources of ESL Literature teaching, namely, theory of language education, the nature of the subject and problematic areas in Literature teaching. The findings may be of benefit to ESL teacher preparation programmes which could use them to provide pre-service teachers with multiple contexts as sources of teaching knowledge.
\end{abstract}

Keywords: beginner teachers; Literature in English; ESL teaching knowledge; ESL teacher preparation

\section{INTRODUCTION}

This paper draws from a doctoral study that explored the way ESL teachers construct teaching knowledge for Literature as a stand-alone subject. The purpose of this article was to identify beginner teachers' sources of knowledge for teaching Literature in English Second Language (ESL) classrooms. Research on teacher knowledge in ESL has tended to overlook Literature in English as a stand-alone subject. Literature in English is the name of a subject presented in the high school curriculum (Zimbabwean Ordinary Level Syllabus [ZOLLS], 2013). The focus of Literature in English is on the appreciation and interpretation of artistic and literary works from English-speaking authors such as Christopher Marlowe, Walter Raleigh, William Shakespeare, John Milton, Geoffrey Chaucer, Francis Bacon, John Donne, Alexander Pope, Jane Austen, Thomas Hardy, Charles Dickens, Oscar Wilde, T.S. Elliot and Maya Angelou and works of non-native English authors such as Chinua Achebe, Mariama Ba, Ngugi wa Thiong'o and Henrick Ibsen.

In Zimbabwe, an Ordinary Level (O Level) beginner English teacher is regarded as being capable of teaching the linguistic and literary aspects of English. O Level is a two-year course presented in Zimbabwean high schools for learners between 15 and 17 years of age. The course was adopted from the British General Certificate in Education (GCE) Ordinary Level (Kanyongo, 2005). A beginner teacher in the context of this study refers to individuals who hold a Diploma in Education and have been in service for less than five years. During their preparation programme, these beginner English teachers undergo a curriculum that seemingly 
equips them with knowledge for teaching both the language and literature domains. However, Uzun (2016) states that most ESL teacher training programmes adequately prepare a teacher in English Language, with some appreciation of Literature teaching.

In the high school curricula which the teachers eventually teach, English Language and Literature in English are taught as separate subjects. The O Level curriculum requires English teachers who possess a meta-cognitive understanding of Literature in English as a stand-alone subject, which is in contrast to the integrated form that they went through during their teacher training. Researchers such as Fleming and Strevens (2015) and Gordon (2012) confirm this inadequacy as emanating from a general fallacy that English Language knowledge preparation is the same as for Literature teaching. The perpetuation of this fallacy lies not only in teacher preparation programmes but is also evident in the teacher knowledge models suggested for ESL teaching, which fail to include teacher knowledge for Literature in English as a standalone subject. Studies in ESL teacher knowledge "formulate a list of should know and should do" for teachers (Gordon, 2012, p.378). Teacher knowledge in Literature in English has been characterised by what Gordon (2012, p.378) calls its "fuzzy, nebulous and difficult nature" due to a lack of research in the area.

The Zimbabwean context in which this study drew from is no different from the situation described by Fleming and Strevens (2015) and Gordon (2012). In Zimbabwe, Literature in English at secondary school context focuses on the study of works by English authors from the Western tradition such as Christopher Marlowe, Walter Raleigh, William Shakespeare, John Milton, Geoffrey Chaucer, Francis Bacon, John Donne, Alexander Pope, Jane Austen, Thomas Hardy, Charles Dickens, Oscar Wilde, T.S. Elliot and Maya Angelou (DiYanni, 2000). Literature in English also focuses on the works of non-native English authors such as Chinua Achebe, Mariama Ba, Ngugi wa Thiong'o and Henrick Ibsen (ZOLLS 2013). The subject emphasises the study of four literary genres, namely, poetry, drama, short stories and novels. ZOLLS (2013, p. 3.0) states that the aim of teaching Literature in English is to stimulate an appreciation of the artistic and aesthetic qualities of Literature; develop learners' reading competence; stimulate analysis, comment and informed judgement on literary texts; and develop the ability to learn and develop from the experiences depicted in Literature. It is clear from the content and genre that Zimbabwean English secondary school curriculum requires of beginner teachers to be able to teach English Language and Literature in English as separate subjects (Department of Teacher Education 2012). However, the Zimbabwean English teacher training programme equips beginner teachers with an integrative form of teaching knowledge which does not distinguish between English Language and Literature in English as stand-alone subjects as required in the secondary school curriculum.

From the discussion of international studies and scholarship on teaching for Literature in English beginner teachers as professionals, and emanating from the ESL tradition, are lacking. In addition, the Zimbabwean situation indicates a gap in teacher knowledge for Literature in English. Notwithstanding, the obvious lack of preparation for Literature in English, beginner teachers in Zimbabwean secondary schools are effectively teaching. Thus the question, the study answered was: What are beginner teachers' sources of teaching knowledge for Literature in English? Olivero (2015) indicates that it is important to unlock beginner teachers' knowledge in the classroom as a way of understanding how their selfreflection influences their teaching practice this study focused on exploring beginner teachers' sources of knowledge for teaching Literature in ESL classrooms. Against this background, this study aimed at building on cross sectional teacher knowledge research in ESL by exploring the sources of teaching knowledge for four ESL Literature in English beginner teachers. 


\section{ENGLISH TEACHER TRAINING IN ZIMBABWE}

Zimbabwean pre-service secondary school teachers are trained at college and university levels. All teacher training colleges resort under the Ministry of Higher Education (MoHE) (Zezekwa, Mudau \& Nkopodi, 2013). In Zimbabwe, college-based teacher training for both primary and secondary schools is coordinated by the University of Zimbabwe's Department of Teacher Education (DTE) (Zezekwa et al., 2013). Under the Scheme of Association, the university, through its Department of Teacher Education (DTE), is the accrediting authority with a mandate of monitoring the quality of teacher education programmes throughout the country (Gondo \& Gondo, 2012). The University of Zimbabwe, as the responsible authority, approves the syllabi for all colleges, examines the students and finally awards the diploma qualification. Each of the colleges is autonomous in terms of curriculum and examinations (Department of Teacher Education, 2012). Individual colleges are responsible for the administration, assessment and quality of their programmes. Before being awarded a Diploma in Education, pre-service teachers are prepared in content and methodology for the teaching of English for five terms (15 months) and one term teaching practice.

The English teacher training curriculum in Zimbabwe is made up of knowledge about language and methodologies of the teaching of English. According to Nyawaranda (1999, p.9), teachers' colleges in Zimbabwe assume "... that student teachers come to the department already equipped with a knowledge of theoretical linguistics, such as grammar and other language skills such as listening, speaking, reading and writing." From this we gather that teachers' colleges equip teachers with methodological knowledge rather than subject knowledge. As Nyawaranda (1999) mentions, there is an assumption that the Advanced Level (A Level) course equips student teachers with the content they need to be subject specialists. English teacher training in Zimbabwe thus regards pre-service teachers merely as reflectors of the preparatory theoretical and subject knowledge of previous educational institutions (Gondo \& Gondo, 2012). Thus, the future for Literature in English is very bleak as the teacher training curriculum focuses on linguistics rather than on literature (Ncube, 2001). Furthermore, the assumption that teachers convey their subject knowledge from $\mathrm{O}$ and $\mathrm{A}$ Levels to teacher training does not hold true for Literature in English. Literature in English is an optional subject in both $\mathrm{O}$ and $\mathrm{A}$ Levels, which means that learners may choose not to study the subject (Nyawaranda 1999). It is true then that some pre-service teachers enter preparation programmes without having taken Literature in English classes.

\section{THEORETICAL MOORINGS}

The theoretical orientation of this study is drawn from a review of the literature on sources of teaching knowledge for English as a First Language, English as a Second Language and English as a Foreign Language and social constructivism. From the available literature, two epistemological positions, namely, theoretical and experiential, exist to explain the sources of teaching knowledge. Theoretically inclined teacher knowledge researchers emphasise teacher training as the source of beginner teachers' knowledge (Turner-Bisset, 1999), while experiential teacher knowledge researchers motivate for classroom practice, experiences and reflective practices as the sources of beginner teacher knowledge (Cheng, Tang \& Cheng, 2012; Elbaz, 1983). However, our understanding of teacher knowledge favours an integrative trajectory that emphasises an exchange between theoretical principles and teacher expertise in the way that these two types of input interact and refine each other (Grossman, Hammerness \& McDonald, 2009; Lampert, 2010). In addition, Shulman (1986, p.6) notes that:

... teachers must not only be capable of defining for students the accepted truths in a domain. They must also be able to explain why a particular proposition is deemed 
unwarranted, why it is worth knowing, and how it relates to other propositions both within the discipline and without, both from theory and practice.

This suggests that the interplay of teachers' theoretical knowledge and experiential practices is critical to the construction of teaching knowledge (Cheng et al., 2012; Hegarty, 2000). We concur with Connelly, Clandinin and He (1997, p.665) that:

... personal practical knowledge is a term designed to capture the idea of experience in a way that allows us to talk about teachers as knowledgeable and knowing persons. Personal practical knowledge is in the teacher's past experience, in the teacher's present mind and body, and in the future plans and actions. Personal practical knowledge is found in the teacher's practice. It is, for any one teacher, a particular way of reconstructing the past and the intentions of the future to deal with the exigencies of a present situation.

From the previous quote, we note that beginner teachers' knowledge has a historical quality which influences their classroom practices.

The integrative nature of teacher knowledge gives it personal and social qualities. As a socially influenced phenomenon, teacher knowledge is personal, practical, contextual and unique (Connelly et al., 1997). Owing to its social nature, teacher knowledge is also conflict and dilemma oriented. Beginner teachers enter the classroom with knowledge from their teacher preparation programmes which they reshape and refine in the face of the conflict and dilemmas inherent in the social environment of the classroom. It follows then that teacher knowledge is a construct of teachers' theoretical and contextual classroom practices (Giovanelli, 2015; Grossman \& McDonald, 2008). This proposition means that teachers are involved in a process of reconstructing theoretical knowledge as they reflect on the practical realities of the classroom and in the process reconstruct knowledge. The reconstructed knowledge contains education theory, which is informed by the theoretical preparation programmes as well as by knowledge gleaned from the contextual and non-generalisable practical aspects that teachers discover through experience (DeGraff, Schmidt \& Waddell, 2015; Grossman et al., 2009). Thus, teacher knowledge is a link in the metacognitive processes that inform teaching and that emanate from both theoretical and experiential knowledge domains.

Our understanding is supported by Calderhead (1996), who comments that teacher knowledge is constructed as a metacognitive function of the teacher's own training and the practical realities that are inherent in any classroom. From this understanding we approached teacher knowledge from a holistic orientation by acknowledging the beginner teachers' theoretical and experiential knowledge as part of their constructed classroom knowledge. Hence, in their teaching knowledge construction, we acknowledged the individual beginner teachers' unique context in terms of their self-image, educational background, classroom practices and the school ethos.

Our understanding of teacher knowledge construction is in line with the social constructivist orientation. Social constructivists believe that teaching is a complex interplay between the teacher and learners, which is based on their classroom experiences (Nagamine, 2007). Social phenomena, of which teaching is a part, must be understood from the social context in which it is produced through observing participants in the environment and how they relate to events in that environment. We bore in mind that beginner teachers' knowledge is shaped by the realities of their classroom. Thus, an appreciation of their classroom practices, which reveal their idiosyncrasies and the multiple realities which they embrace as unique individuals, was an important insight for this study. 


\section{RESEARCH STRATEGY \\ Epistemological viewpoint}

The present study was approached from an interpretivist epistemological worldview. An interpretivist paradigm emphasises meaning and understanding in participants' activities within their contexts (Nieuwenhuis, 2007). It is concerned with a descriptive analysis of participants' understanding of their lived experiences within a historical context (Creswell, 2013). We favoured an interpretivist paradigm for this study as we aimed at exploring the sources of Literature in English beginner teachers' knowledge from their interpretation of experiences in the context of their ESL classroom.

\section{Qualitative approach}

In order to explore the knowledge that Literature in English beginner teachers hold, we used a qualitative approach. Qualitative research allows for attitudes associated with a phenomenon to be understood in the context of the occurrence (Suter, 2006). We embraced this approach as it provided the participants with a voice to share their experiences as Literature in English beginner teachers (Creswell, 2013). From a qualitative trajectory, this study provided detailed experiences of the way beginner teachers' source knowledge for teaching Literature in English. As we did not intend to prescribe the teaching knowledge that Literature in English teachers ought to have, a qualitative inquiry was, thus, important in highlighting the participants' descriptions of their world as beginner teachers (Mertens, 2014).

This study used a single case study design. A case study is "an empirical enquiry to investigate a contemporary phenomenon in a real-life context, especially when the boundaries between the phenomenon and context are not clearly evident" (Yin 2014, p.13). We were cognisant of the fact that, as a bounded unit, participants shared common experiences as new subject teachers (Creswell, 2013). This particularity with beginner teachers as a bounded unit was important in our understanding of their teaching knowledge which had developed from a continuous process of dealing with the challenges inherent in the classroom. Using a single case design, we paid attention to the unique contexts which helped to explain the individual teacher's knowledge in order to produce a holistic picture of the phenomenon (Yin, 2014). Closely related to the above assertion is the notion that a phenomenon binds itself with the context, which means for this study it was important to understand beginner teachers' knowledge from the context of that particular Literature in English classroom.

\section{Purposive sampling}

In this study purposive sampling was used to select the participants. According to Creswell (2013), purposive sampling is employed to select participants that have defining characteristics which are crucial in answering the research questions and providing in-depth and rich data. In this study, participants with the following characteristics were selected: (i) beginner teachers; (ii) teaching in any school in Bulawayo East and (iii) teaching form three learners in Literature in English. Form three is the first academic grade in the O Level course. The learners in this academic grade are usually between the age group 15-16. From these criteria, four beginner teachers, referred to as A, B, C and D, were selected.

\section{Setting of the study}

The purpose of the study was to explore beginner teachers' sources of knowledge for teaching Literature in ESL classrooms from Bulawayo East District in Zimbabwe. The schools that resort under Bulawayo East District are former group A schools. What this means is that these schools were reserved for white students prior to 1980 when Zimbabwe gained her independence and the school system was desegregated. The four sampled schools are located in residential areas that was during the pre-independent Zimbabwe reserved for white learners. 
The area is currently occupied by middle class black people and a few white families. Thirtysix (36) years after the desegregated system, the four sampled schools still have a residual identity to the British curriculum which included the study of Literature in English. In Zimbabwe, English Language, History, Mathematics, an indigenous language and General Science are considered as core subjects which every learner in the secondary school system should study and write a national examination in, Literature in English is optional. What this means is that $\mathrm{O}$ Level learners may decide not to read it. In fact, in other schools especially in the resource-constrained areas, Literature in English is not studied.

The participants in this study comprised four O Level Literature in English beginner teachers. We held that for us to recognise the theoretical and experiential preferences of each beginner teacher participant, there was a need to understand their autobiographical journey into teaching.

Participant A was a 27-year-old woman. She had been a teacher for four years. Participant A's story into teaching was one of determination to make a difference through the classroom. Through empowering the girls in her class with the ability to think and act, Participant A believed that she was contributing to their mentorship as independent thinkers. She loved to act and participate in public speaking. Her greatest love was teaching and empowering learners, especially the girl child.. She was soft-spoken, but easily excited by a discussion about her teaching.

Participant B is a 26-year-old woman who has been a teacher for four years. Participant B, found teaching Literature in English exhilarating but challenging. Interestingly, teaching was not her first love, as she dreamt of being a lawyer. Her dream was to be a lawyer but she failed to obtain the university entry requirements to study to become one. Teaching, she said, came as her third choice, but she has grown to love teaching Literature in English. She found the challenges inherent in the school system difficult to navigate. We observed that she approached teaching with a lot of frustration that she could only express in tears...

Participant C was a 28-year-old woman who has been a teacher for four years. Participant C's journey into teaching was pre-determined by a religious calling. She considered teaching as a pastoral vocation. She believed that she was called into the ministry of teaching. Coming from a religious background, Participant $\mathrm{C}$ assigned teaching an exclusiveness that is usually associated with religious ministry - she believed she was shepherding rather than teaching the learners. She lost her mother when she was 20 years old. Since then she has been the mother figure for her siblings. She considers teaching her calling; she says God chose her to be a teacher.. Participant C's class was warm and welcoming.

Participant D was a 25-year-old female teacher who has been in the service for four years. She knew she wanted to be a teacher in high school already, because of her English teacher who went out of her way to create an enabling environment in their impoverished rural school. Participant D regarded teaching as a mentorship journey. She saw herself as mentoring her learners for academic and life excellence. She radiated a charisma and individuality, which made it easy to relax in her company. We found her self-motivated, self-reliant and nonconformist.

\section{Data collection and analysis}

The qualitative approach favoured in this study focuses on a holistic inquiry into a phenomenon in its natural settings (Suter, 2006). Thus this study used qualitative methods of data collection to explore the sources of the beginner teachers' knowledge for teaching Literature in English. We used two research methods as we sought for "convergence and collaboration" (Bowen 2009, p.28), and we reasoned that multiple methods provided "a confluence of evidence that breeds credibility". Data were collected semi-structured interviews. Semi-structured interviews were used because of their strength in giving 
prominence to the participants' meaning of their lived experiences (Mertens, 2014). All the participants went through four interviews which lasted between 30 and 35 minutes. We approached the semi- interviews from an understanding that "our knowing is ordinarily tacit, implicit in our patterns of action and in our feel for the stuff with which we are dealing. It seems right to say that our knowledge is in our action" (Schön 1983, p.49). We were aware that unless the participants were questioned about their teaching practices, they would consider them as ordinary and irrelevant. In the fourth interview, we gave the participants the opportunity to reflect on their teaching practices. We asked them to discuss the teaching knowledge gaps that they encountered in teaching Literature in English and the strategies they used to minimise these gaps when they occurred.

In line with the qualitative approach embraced in this study, data from the semistructured were transcribed and analysed using inductive thematic analysis. According to Braun and Clarke (2006), inductive thematic analysis is used when the researcher intends to explore and identify the recurring themes in the data. Creswell's (2009) framework for data analysis was applied; that is, organising and preparing the data, reading the data, coding and segmenting the data accordingly, and then interpreting the data in line with current research on teacher knowledge.

\section{QUALITY CRITERIA}

Quality in this study was achieved through the following strategies: triangulation, prolonged field engagement, member checks, thick descriptions and an audit trail (Marshall \& Rossman, 2010; Shenton, 2004). In keeping with the selected quality strategies, we collected data using multiple research instruments so as to improve the internal consistency of the data. Furthermore, prolonged engagement was used as a way of familiarising ourselves with the participants' contexts, and was aimed at improving the emic experience we needed to understand the participants' sources of teaching knowledge. Through member checking we confirmed that we had captured the participants' voices and given prominence to their interpretation of their sources of teaching knowledge. We also provided thick and extensive descriptions of the methodology and context of the study. Using thick descriptions, we captured the cultural context in which the beginner teachers practised their profession. In addition, the trail provided by the observation video tapes, interview transcripts and field notes was audited to ensure authenticity.

\section{ETHICAL CONSIDERATIONS}

To safeguard the participants from any form of harm, ethical issues were taken seriously in this study. The Faculty of Education at the University of Pretoria granted us an ethical clearance certificate. Permission to engage with the beginner teachers in Bulawayo East was sought and granted by the Provincial Education Director and the individual principals in each of the four schools that participated in this study. The participants were invited to participate in the study and were assured of confidentiality, anonymity and the right to withdraw from the study at any time. Parental and guardian permission and the learners' assent were sought to video record the learners who were not part of the study but who were present during the class observations.

\section{FINDINGS}

From the analysis, three themes emerged to explain the beginner teachers' sources of teaching knowledge for Literature in English. The three themes are teaching knowledge from theory of language education; the nature of the subject; and problematic areas in Literature in English. The themes are discussed in detail below. 


\section{Teaching knowledge from theory of language education}

All the participants agreed that they possessed general knowledge of teaching from their teacher training programmes. The participants' general knowledge of language teaching was extended to the teaching of Literature in their classroom. The participants emphasised that they had personal philosophies that informed their Literature teaching. These philosophies are based on the theory of education acquired during their training. The philosophies are self-defined descriptions of what they hope learners embrace from their classroom teaching. Participant A stressed that she favoured teaching that empowered learners:

I am empowering the learners. They have to learn the subject independent of my way of thinking. They must understand that the teacher only guides them. They must research and discover on their own (Participant A, Interview, 14/03/2016).

During the observation in Participant A's class, we identified some of her philosophies in action. For example, she asked the group that was presenting during the second observation to speak loudly. She went on to say that the world would not have patience for women who appear apologetic about who they were. She said:

When you go in front of an audience, Martha (pseudonym name given to the learner), show them you are a woman who knows her place" (Observation notes, 10/02/ 2016).

Participant B, on the other hand, mentioned that her teaching was influenced by her belief that it was a partnership between the teacher and the learners:

Peer teaching is a good way of teaching. The learners, in their groups or in pairs, research on specific topics and present them in class. As a teacher, I work as a guide. The students have to discover on their own. I have also realised that it is a way of boosting their confidence. I feel as if I am whispering to them that they are responsible enough to be teachers (Participant B, interviews, and 18/03/2016).

Participant B teaches at a modern school with smart boards, interactive e-learning platforms and internet connectivity. However, we failed to identify how Participant B used the available resources to enhance her teaching. We sensed that there was a slight difference between what she hoped her class to be and her actual teaching. With all the interactive platforms available to her, Participant B dictated notes to learners during all of my visits to her classroom. Participant $\mathrm{C}$ talked about responsible teaching. She explained that she allowed her learners to be involved in making decisions about how they learn. She noted that:

The pupils should be part of the lesson, this helps them retain information, and this helps boost their confidence. You realize when a pupil gives a correct answer, I affirm. I am trying to boost their confidence - help them feel good about the answer they have given so that next time they can also participate. I spoke about life skills in the previous interview. I am teaching them to talk; I do not want Literature pupils that are docile and unable to express themselves, so language skills are being developed as they participate (Participant C, interview, 06/04/2016).

The learners in Participant C's class were responsible for decisions on their class attendance. Her class was interesting to observe because of the tranquil atmosphere that became immediately apparent as one entered the class. I found the learners highly motivated and focused; for a minute I forgot that I was in a class with teenagers. Participant D's teaching is based on her understanding that teaching is a partnership. She commented that she viewed teaching as a partnership between her and her learners.

The participants explained that their teaching knowledge changed according to the context and the nature of the learners in the class. Both Grossman and McDonald (2008) and Hegarty (2000) note that teachers' way of teaching is influenced by their personal beliefs on how the practice of teaching should be. In agreement, Participants A, B, C and D respectively viewed teaching as empowering, interactive, a partnership and participatory. This implies that their general teaching practice is a function of their worldview. For example, Participant D, whom we surmised was a pragmatic beginner teacher, was involved in class activities such as research, presentations, peer and group work and role-plays, which had been common activities in her teaching orientation. 


\section{Teaching knowledge from the nature of Literature in English}

The participants argued that they knew that the nature of Literature in English required a certain way of thinking and involvement from learners. Participants A and B indicated that, for effective teaching to take place, Literature in English beginner teachers should know the history of literature, which informs its nature:

Literature is a subject of royalty. From my reading, in England, it was a subject of the royal family, the intellectuals; people who thought deeply. Everyone who is a learner in the subject should get involved. That is how it can be interesting and meaningful. You need to be involved, think, and make your own analysis about what you are reading (Participant A, interview, 14/03/2016).

In addition, having knowledge of the nature of the subject meant that the beginner teachers were aware of the skills needed for the learners to perform well in the subject.

The nature of the subject requires the pupils' own analysis. It requires what they think. Even when they write examinations, they have to include first-hand information. The nature of the subject again, calls for pupil involvement. They have to be part of the lesson. They have to be involved in the learning rather than being passive. That is why they have to think and be able to analyse and go and research, present and argue. There are questions that require them to argue so if they are passive and they are used to just receiving information when the examination comes and a question requires them to present an argument, how will they be able to do it if they do not practice? (Participant A, interview, 14/03/2016).

The participants commented that they knew that the history of Literature in English was important in understanding how it should be taught. Literature in English is a subject that was once reserved for royalty; its teaching ought to be approached with such seriousness. The participants knew that learners needed to think while learning Literature in English. However, when probed further, the participants failed to explain what they meant by thinking. I observed that it was a commonly used word in the Literature in English class, but was not planned for in the teachers' scheme books.

The participants noted that knowledge of the nature of Literature in English motivated them to embrace specific teaching methods. Participant A commented that she assessed the classroom situation before using a particular teaching method:

You have to assess the situation and use the methods which are applicable at that particular time depending on the calibre of the students that you are teaching. When we are studying plays, we normally dramatize. For example, with The Merchant of Venice we did a lot of dramatization because a play is actually meant for the stage. We also dramatized novels like A Cowrie of Hope. We would pick a few chapters that we used. Besides going to research on essay questions, the students also engage in debates on the novel's thematic issues. I can give you an example of one debate question that we once had on The Merchant of Venice. Shylock is responsible for his downfall, do you agree? They had to present a debate on that. While some are saying he is responsible others are saying no. The evidence they use is strictly from the text (Participant A, interview, 14/03/2016).

Participant A's teaching methods in Literature in English included drama, essay writing and debates. She also added an interesting aspect of her pedagogical knowledge, as she included repetition as a way of improving learners' knowledge retention. She knew that through emphasis and repetition learners could master literary concepts and skills. Participant $\mathrm{C}$ noted that before deciding on a teaching method to be used in Literature in English, there is a need to know the learners and their weaknesses. She noted that Literature in English was learnt through interactive methods such as group work, classwork and class presentations. Participant D knows that the use of drama, discussion, role-play, code switching, inter-subject learning, and e-learning platforms such as blogs, enhance the learning experience in Literature in English. Participant B acknowledged that some methods are specific to teaching Literature such as e-learning platforms, but she was unsure how she integrated them into her teaching. She stated that learners used the internet for research; she occasionally screened Shakespearian movies but she integrated them to her teaching as a whimsical afterthought. I believe that elearning platforms are very important in her Literature in English class. Participant B stated that "...learners are able to comprehend concepts through interactive means such as pair work, class discussion, blogs and WhatsApp" (Participant Interview, 18/03/2016). Participant B 
might be unaware that she had formulated ways of teaching Literature in English that were not commonly used, as methods such as blogs and WhatsApp appeared to be part of her teaching methods.

Participants sourced their teaching knowledge from an understanding of the nature of Literature in English and methods for teaching Literature in English. Both Turner-Bisset (1999) and Shulman (1987) conceptualise teacher knowledge as including pedagogical content knowledge (PCK). However, they define PCK differently. Shulman (1987) defines teachers' PCK as a combination of content and pedagogical aspects of a subject, while Turner-Bisset (1999) regards it as an integrative domain that includes all the knowledge that teachers have on a subject. The participants in this study seemed to be aligned with Shulman's definition, as they believed that PCK was a combination of knowledge of the nature of the subject (content) and methods of teaching (pedagogy). The participants agreed that there was a unique way of teaching Literature in English that was different from the teaching of other subjects.

In line with the findings of Cheng et al. (2012), Lampert (2010) and Buitink (2009), the participants' theoretical knowledge of teaching methods was reconstructed practically in the classroom to suit the learners' context and the area of study in Literature in English. Thus, the teachers' classroom experiences informed the type of methods they used to teach the subject. Participants A and B noted that Literature was learnt through allowing learners to read the literary works, conduct research and give presentations in class. Participant $\mathrm{C}$ argued that Literature in English was easily taught by allowing for class reading, group work and class presentations. On the other hand, Participant D stated that Literature in English was learnt through other subjects like History and Geography and by using different venues to teach, such as teaching in a park or next to a dam. Every method that the participants suggested highlighted their understanding of the nature of Literature in English as a subject and their knowledge of methods that motivate their learners. In accordance with Shulman and Shulman's (2004) understanding of PCK, the participants indicated that their PCK was a result of interplay between their theoretical persuasions and their experiential orientations.

From the findings, we came to the realisation that teachers' knowledge was not constructed once but was rather a function of reflection on the practice of teaching Literature in English, which is a continuous process. We understood then that teachers were in a continuous process of refining their ability to teach a subject. The key elements of this reflection on practice with regards to PCK appear to be the context, the learners and the curriculum objectives. The implication is that subject knowers, not subject teachers, create PCK. We believe that subject knowers have the ability to recognise the instruction methods that could enhance teaching. Similar to the findings of DeGraff et al. (2015) and McGlynnStewart (2015), the participants in this study indicated that their PCK was integrative, as it integrates the context, the learners and the curriculum objectives for effective teaching to take place. Its integrative characteristic means that if one of the aspects is omitted, PCK is rendered useless. For example, having a good method to teach Literature in English without knowledge of the curriculum and its objectives produces ineffective teaching.

\section{Teaching knowledge sourced from problematic areas in Literature in English}

The participants discussed their teaching knowledge as coming from the comprehension of learners' problematic areas in learning Literature in English. These problem areas result from their academic ability and the contextual nuances in each school. Learners placed in Literature classes are usually considered by the school and their peers to be low achievers. This a far cry from the esteemed position that Literature previously held as a subject of royals (Participant A). In fact, Participant D states that in her "...school, Science, technology and mathematics are given more prominence than the arts subjects." This point is further supported by Participant $\mathrm{C}$ who started that "... it is the weak students that have failed to make 
it to the science classes that find themselves in my class". In response to the low regard of Literature in the four sampled school, all the participants indicated that they developed scaffolded strategies of teaching Literature as a way of motivating their learners. Participant $\mathrm{C}$ indicated that they had knowledge of how to counsel learners as a way of boosting their selfesteem:

I sometimes have counselling lessons where we do not have Literature lesson but a counselling lesson. The students state their problems and we discuss them. The first lesson I had with them was a discussion on the syllabus. I then talked to them candidly because sometimes they feel inferior as they are labelled weak students. I made them understand that they are high performers. I promised I would help them achieve their goals. Once you create that excitement and self-value, they seem to understand the subject better. As you saw them during the observations, did they appear as weak students? (Participant C, interview, 06/04/2016).

This suggests that teachers' knowledge of learners' academic ability inexorably leads them to another knowledge construction, one which deals with strategies to motivate learners in a Literature in English class.

The teachers' knowledge of the learners' academic ability has led them to knowledge on how to motivate learners in Literature in English. Each participant had come up with certain strategies that they believed motivated their learners to attain literary competence. Participant A used participatory class activities such as drama to motivate her learners. Participant B revealed that she at times used dictation as a teaching method because she knew her learners needed such motivation to learn. Participant $\mathrm{C}$ shared that she knew that her learners appreciated being loved and cared and used this as a way of motivating them. Participant D extended Literature in English learning to the pupils' own lives to create an appreciation of literature and the retention of literary knowledge.

The participants indicated that their learners learn Literature in English through interaction, research, indigenous artistic techniques (song), interpretation, memorisation and elearning platforms, as well as by using practical skills that are related to their life outside the school. The use of learner-centred methods also motivated pupils to learn Literature in English. According to Participant D, learners perform better in Literature in English if it is taught practically:

I have made my HoD realize that I teach the way learners want me to. I try to run away from routine behaviourist teaching. You saw that the pupils were few in class. It is because some of them have already passed the subject in the June examinations. 11 wrote and all of them passed with seven As and four Bs and I know the remaining 24 will pass and this is a class which everyone considers as low achieving (Participant D, interview, 08/04/2016).

The participants all used some form of scaffolding to nurture learners' academic growth. The scaffolding process begins with learners' involvement in class as individuals, in pairs and in groups until they grow to be researchers and presenters in Literature in English. Participant D regarded learners' academic growth as related to their ability to use skills from the classroom in their daily life, which was aligned to her pragmatic approach to teaching:

They need to present ideas that are practical. I am preparing them for life. They should know that life is not a bed of roses. Literature can help them known that hard work pays like was the case with Nasula and Sula in A Cowrie of Hope. Literature should also help them to know how to fight for themselves. I do not want them to be docile recipients of everything. They need to learn that at times you have to fight in order to be recognised (Participant D, interview, 08/04/2016).

The participants' knowledge of the learners included knowing their characteristics, including their cognition, learning and motivation. The participants also acknowledged that they possessed knowledge of the learners. This knowledge includes the learners' ability and the strategies that motivate them to attain Literature in English competence. The participants noted that the difficulties learners experienced with a subject could largely be traced back to their attitude towards the subject. The participants suggested that knowing learners' attitudes towards a subject was important in understanding their academic performance. They stated that learners' performance in a subject might not be an indication of their intellectual abilities, but 
of their attitudes. In this context, the participants highlighted that they had generated strategies which comprised motivational tactics aimed at minimising negative learner attitudes towards the study of Literature in English.

\section{DISCUSSION}

The findings highlighted that teachers source their teaching knowledge from the theory of education, the nature of the subject and the problematic areas encountered in teaching knowledge. The literature on which this study was underpinned was drawn from cross disciplinary research on teacher knowledge. For example, literature in English as a first language, English as a second language and English as a foreign language. Hence the findings of this study might provide insights across disciplines in the construction of English teaching knowledge. The findings extend the study's conceptual framework, which was drawn from a literature review on theoretical and experiential teacher knowledge. We conceptualised that beginner teachers construct their Literature in English teaching knowledge by integrating their theoretical and experiential knowledge. We rejected the separation of teacher knowledge domains according to the theoretical or experiential orientations, as we believe that beginner teachers use all the knowledge at their disposal to make sense of their teaching. The beginner teachers in this study held theoretical knowledge from their teacher training programmes as we conceptualised. Corresponding with the study's conceptual framework, the beginner teachers in this study were involved in a process of contextualising and personalising theoretical teaching knowledge to address their classroom needs. From this process of reordering theoretical knowledge to meet contextual needs, the beginner teachers acquired teaching knowledge that was individualistic, contextual and pragmatic. However, the beginner teachers did not explicitly separate theoretical and experiential knowledge in their teaching but rather integrated the knowledge as part of their overall professional practices.

In contrast with our conceptualisation of teaching knowledge as being constructed from an amalgamation of theoretical and experiential knowledge, the beginner teachers indicated a more elaborate construction schema. Although acknowledging the theoretical and experiential knowledge as sources of their teaching practices, the beginner teachers in this study indicated that their construction developed from past, present and anticipated classroom experiences. They highlighted that teaching knowledge construction involved multiple sources that included previous educational experiences, present Literature in English experiences and anticipated classroom experiences.

The beginner teachers came to possess an idiosyncratic Literature in English teaching knowledge from "an embryonic manifesto of the teacher-self that emerges during a beginning teacher's formative experiences, both as a student at school and university, and during their initial teacher education" (Giovanelli, 2015, p.3). The embryonic nature of teacher knowledge suggests an interrelatedness of its complex conception that draws from personal, professional and contextual frameworks. This suggests that teacher knowledge results from an interplay of professional and contextual nuances that lead to a personalised way of teaching. Although the beginner teachers have some similar comprehension about teaching Literature in English, how they approach it will be determined by their experiential worldview. This means that the beginner teachers' previous educational experiences, which included their time as students in teachers' colleges and high schools, provided them with the knowledge that set them on the path to teaching. Interestingly, the classroom experiences eventually revealed to the beginner teachers that their theoretical knowledge was incomplete and, as they reflected on this, they constructed knowledge that was personal, unique, reactional, contextual and practical. The beginner teachers' present experiences in the Literature in English classroom and their further academic and professional development also combine to influence their teaching knowledge. 
At the anticipatory level, the beginner teachers planned for the future through a dialogue with the learners, school expectations and knowledge of the syllabus. Through the anticipatory process, the teachers constructed a scaffolded classroom in which learners' weaknesses were anticipated and identified, and then possible strategies spontaneously created to minimise them.

\section{Implications for ESL teacher knowledge}

The strength of the single case study is its ability to provide a methodological lens to explore a phenomenon from participants' natural settings, which provides a holistic portrait. This merit was what we needed in this study for a deeper comprehension of beginner teacher knowledge. Thus, in setting out the criteria for the selection of the sample, it was not the intention to get a representative sample but to select a sample that would yield answers to the research question. For this purpose, four beginner teachers were sampled which means the findings of this study cannot be generalized to other contexts. Notwithstanding the fact that that the findings cannot be generalized beyond the context of the study, the insights derived from it can be explored for in-depth understanding of teacher knowledge across disciplines.

Teacher knowledge, as suggested by the study's findings, is located in the teachers' past, present and anticipated classroom experiences. From a constructivist understanding, the study acknowledges the symbiotic relationship between theoretical knowledge in teaching and the role of teachers in the construction of their teaching knowledge from classroom-based experiences. These findings emphasise teaching knowledge as emanating from personal, practical, reactional and contextual experiences, which means teacher preparation programmes might better prepare pre-service teachers by exposing them to multiple contexts which have the potential to develop their professional practice.

From the reviewed literature, and based on the findings from this study, it would seem that there is a need to carry out further studies in the area of Literature in English teacher knowledge models. As this study was a maiden voyage, and was carried out in one area of Zimbabwe, there is a need for more research in ESL and in broader contexts to further understand the multiple sources of teaching knowledge in Literature in English which different research contexts could provide.

\section{References}

Bowen, G, A. (2009). Document analysis as a qualitative research method. Qualitative Research Journal, 9 (2), 27-40.

Braun, V. \& Clarke, V. (2006). Using thematic analysis in psychology. Qualitative Research in Psychology, 3, (2), 77-101.

Buitink, J. (2009). What and how do student teachers learn during school-based teacher education? Teacher and Teaching Education, 25(1), 118-127.

Calderhead J. 1996. Teachers: beliefs and knowledge. Retrieved 12, December 2016, from www.psycnet.apa.org

Cheng, M.M., Tang, S.Y. \& Cheng, A.Y. (2012). Practicalising theoretical knowledge in student teachers' professional learning in initial teacher education. Teaching and Teacher Education, 28(6), 781-790.

Connelly, F.M., Clandinin, D.J. \& He, F. (1997). Teachers' personal practical knowledge on the professional knowledge landscape. Teaching and Teacher Education, 13(7), $665-674$.

Creswell, J.W. (2009). Research design: qualitative, quantitative, and mixed methods approaches. 3rd edition. Thousand Oaks, CA: Sage.

Creswell, J.W. (2013). Qualitative inquiry and research design: choosing among five approaches. 3rd edition. Thousand Oaks, CA: Sage 
DeGraff, T.L., Schmidt, C.M. \& Waddell, J.H. (2015). Field-based teacher education in literacy: preparing teachers in real classroom contexts. Teaching Education, 26(2), $1-17$.

DiYanni, R. (2000). Literature: reading fiction, poetry, and drama. Columbus, $\mathrm{OH}$ : McGraw-Hill Education.

Elbaz, F. (1983). Teacher thinking: a study of practical knowledge. London: Croom Helm.

Fleming, M.P. \& Strevens, D. (2015). English teaching in secondary schools: linking theory and practices. $4^{\text {th }}$ ed. London: Routledge.

Giovanelli, M. (2015). Becoming an English language teacher: Linguistic knowledge, anxieties and the shifting sense of identity. Language and Education, 29(5), 416-429.

Gordon, J. (2012). More than canons: teacher knowledge and the literary domain of secondary English curriculum. Educational Research, 54(4), 375-390.

Grossman, P., Hammerness, K. \& McDonald, M. (2009). Redefining teaching, re-imagining teacher education. Teachers and Teaching: Theory and Practice, 15(2), 273-289.

Grossman, P. \& McDonald, M. (2008). Back to the future: directions for research in teaching and teacher education. American Educational Research Journal, 45(2), 184-205.

Hegarty S. (2000). Teaching as a knowledge-based activity. Oxford Review of Education 26(4), 451-465.

John, P.D. (2002). The teacher educator's experience: case studies of practical professional knowledge. Teaching and Teacher Education 18(3), 323-341.

Kanyongo, G.Y. (2005). Zimbabwe's public education system reforms: successes and challenges. International Education Journal, 6(1), 65-74.

Khatib, M., Rezaei, S. \& Derakhshan, A. (2011). Literature in EFL/ESL classroom. English Language Teaching 4(1), 201-208.

Khatib, M. \& Nourzadeh, S. (2011). Some recommendations for integrating literature into EFL/ESL classrooms. International Journal of English Linguistics 1(2), 258-263.

Lampert M. (2010). Learning teaching in, from, and for practice: what do we mean? Journal of Teacher Education, 61(1), 21-34.

Marshall, C. \& Rossman, G.B. (2010). Designing qualitative research. Thousand Oaks, CA: Sage.

Mertens, D.M. (2014). Research and evaluation in education and psychology: integrating diversity with quantitative, qualitative, and mixed methods. 4th ed. Thousand Oaks, CA: Sage.

McGlynn-Stewart M. (2015). From student to beginning teacher: learning strengths and teaching challenges. Cogent Education, 2(1), 1-18.

Morrison, J.W. (1988). Consultancy to advise on program to enhance communication skills in teacher education. Edinburgh: Scottish Centre for Education Overseas, Moray House College.

Nagamine, T. (2007). Reconceptualising teacher knowledge and belief based on social constructivism. Journal of the Faculty of Letters, Prefectural University of Kumamoto, 13(66), 1-13.

Nieuwenhuis, J. (2007). Analysing qualitative data. In K, Maree. (ed.), First steps in research (pp. 98-122). Pretoria: Van Schaik.

O'Connor, Z. (2011). Colour psychology and colour therapy: caveat emptor. Color Research \& Application, 36(3),229-234.

Olivero, M.M. (2015). Multilingualism in an EFL practicum: increasing student teachers' pedagogical knowledge. TESOL Journal, 6(2), 382-404.

Savvidou, C. (2004). An integrated approach to teaching literature in the EFL classroom. The Internet TESL Journal, 10(12), 1-6. 
Schön, D. A. (1983). The reflective practitioner: how professionals think in action. London: Basic Books.

Shenton, A. K. (2004). Strategies for ensuring trustworthiness in qualitative research projects. Education for Information, 22(2), 63-75.

Shulman, L.S. (1986). Those who understand: knowledge growth in teaching. Educational Researcher, 15(2), 4-14.

Shulman, L.S. 1987. Knowledge and teaching foundations of the new reform. Harvard Educational Review, 57, 1-23.

Shulman, L.S. \& Shulman, J.H. (2004). How and what teachers learn: a shifting perspective. Journal of Curriculum Studies, 36(2), 257-271.

Suter, W.N. (2006). Introduction to educational research: a critical thinking approach. Thousand Oaks, CA: Sage.

Turner-Bisset, R. (1999). The knowledge bases of the expert teacher. British Educational Research Journal, 25(1), 39-55.

Uzun, L. (2016). Evaluation of the latest English language teacher training programme in Turkey: Teacher trainees' perspective. Cogent Education, 3(1): 11471165.

Van, T.T.M. (2009). The relevance of literary analysis to teaching literature in the EFL classroom. English Teaching Forum, 3(1), 2-9.

Yin, R.K. (2014). Case study research: design and methods. 5th edition. Thousand Oaks, CA: Sage.

Zimbabwean Ordinary Level Literature Syllabus (2013). Retrieved on 7, December 2015, from http://www.mopse.gov.zw/index.php/o-level?download=227:0-level-englishliterature-pdf 